\title{
The Dynamics of Ethnic Conflict in Southern Province Thailand
}

\author{
Andi Firmansah \\ International Relations Department, Universitas Muhammadiyah Yogyakarta, Indonesia \\ Email: andifirman08@gmail.com
}

Submitted: 14 November 2019 | Accepted: 22 Desember 2019

\begin{abstract}
This paper explains how the ethnic conflict process that occurred in the Southern Province of Thailand to the process of resolving conflicts between the Government of Thailand and local residents in the Southern Province of Thailand. The conflict is based on the history of the Southern Thailand region between the Thai Government and the Malay Muslim population. Then, it caused conflicting attitudes and behaviors in responding to this conflict from each of the warring parties. This paper uses the concept of the conflict triangle from Johan Galtung where this conflict comes from perceptions based on historical differences, then followed by differences in conflicting behavior from each party and differences in interests. Then, using the concept of the source of conflict from Bernard Meyer, the source of the conflict that comes from historical differences so that it affects how to communicate, emotional reactions, values and structures owned. Then, using the concept of the stage of conflict resolution from Johan Galtung, this conflict is at the peacekeeping level where Malaysia is the mediator between the two warring parties. In resolving conflicts, both parties need to change attitudes and behavior in transforming different interests.
\end{abstract}

Keywords: Ethnic, Conflict, Resolution, Southern, Thailand.

\begin{abstract}
Abstrak
Tulisan ini menjelaskan bagaimana proses konflik etnis yang terjadi di Provinsi bagian Selatan Thailand hingga proses penyelesaian konflik antara Pemerintah Thailand dan penduduk setempat di Provinsi bagian Selatan Thailand. Konflik yang terjadi berdasarkan sejarah wilayah Thailand Selatan antara Pemerintah Thailand dan penduduk Muslim Melayu. Kemudian, menyebabkan sikap dan perilaku yang bertentangan dalam merespon konflik ini dari masing-masing pihak yang bertikai. Tulisan ini menggunakan konsep segitiga konflik dari Johan Galtung dimana konflik ini berasal dari persepsi yang didasarkan pada perbedaan sejarah, kemudian dilanjutkan oleh perbedaan perilaku yang bertentangan dari masing-masing pihak dan perbedaan kepentingan. Kemudian, dengan menggunakan konsep sumber konflik dari Bernard Meyer, sumber konflik yang terjadi berasal dari perbedaan sejarah sehingga mempengaruhi cara berkomunikasi, reaksi emosional, nilai dan struktur yang dimiliki. Kemudian, dengan menggunakan konsep tingkatan penyelesaian konflik dari Johan Galtung, konflik ini berada pada tingkatan peacekeeping dimana Malaysia menjadi mediator diantara kedua pihak yang bertikai. Dalam menyelesaikan konflik, kedua pihak perlu untuk mengubah sikap dan perilaku dalam mentransformasikan kepentingan yang berbeda.
\end{abstract}

Kata kunci: Konflik, Etnis, Resolution, Southern, Thailand.

\section{PENDAHULUAN}

The existence of a state cannot be seperated from the interaction of its citizen. Usually, the people within state will belong to some tribes or ethnics.

It is coming from their parents who also belongs to some tribes or ethnics. In some moments, the people will also have their own religion or belief as the 
citizens. Later, the people will interact with other people coming from their same or different ethnic and beliefs. Their interaction will result to their descendants who then they become the next citizen live in a state. The total of people who belong to some ethnics compared by the whole total of people in a state may determine that particular ethnics considered as the majority or minority. For instance, in Indonesia, according to Badan Pusat Statistik (BPS), from hundreds ethnic that exist, Javanese put as the majority with the percentage $40,05 \%$ from whole total of Indonesia people and Islam also as the majority religion in Indonesia with the percentage 87, $18 \%$ (Badan Pusat Statistik, 2015).

As the citizen of a state, the people will do their responsibilities and also they will get their rights from the state represented by the government. For example, the citizens have to pay tax to the state as one of their responsibilities and the government will provide some infrastrcuture as the fasilities for the right of citizens. Beside that, each citizen will also be protected by the state like having religion.

As what existing in world situation nowadays, some ethnic groups in some countries are categorized as the minority and they have to face difficult condition to be the minority. As the minority groups, they might be treated different from other majority groups. It may come with the reason of different of culture, attitude, language and religion; government policies form, laws and economic system; and the opposite group. Those differences raising among the ethnics (between majority and minority) may lead to the conflict. It can be the conflict between the government and the people or among the people.

According to Surwadono, conflict phenomenon exists among the people that mostly happened in republic states rather than state with monarchy system. He argued that it caused by the greater democracy index rate in republic states compared to the state with monarchy system. Moreover, in conflict among the people, it is mostly caused with the dimension of ethnic, religion, race and inter-group (SARA/Suku, Agama, Ras dan Antar golongan).

The writer will discuss the conflict happened in Southeast Asian countries. In Philippines and Thailand, the position of majority and minority group contribute to the ongoing of conflict. The case of Mindanou and Patani were considered as the conflict between the regimes dominated by the majority and group and faced the minority group. Moroever, the majority group will usualy claimed their group as the national identity in 
their state. Meanwhile in some of Indo-China countries, conflicts that happened represent as the disagreement of authoritarian and repressive state policy towards the citizen. They will only run the program from the government because there is no other possible alternative reason they could choose.(Surwandono \& Ahmadi, 2011).

In other countries located in Southeast Asia, the conflict that based on religious ideology and political ideology mostly happened. The location of Southeast Asia as the intercontinent bridge causes the spread and exchange of religious and political ideology becomes so rapid. As what happened in Indonesia, the debate between two biggest muslim organizations, Nadhlatul Ulama (NU) and Muhammadiyah had escalated until its climax point in 1970s. In Malaysia, the rising of al-Arqom organization under the leadership of Ustadz Azhari Muhammad had made this organization considered as prohibited and perverted organization spreading in Malaysia.

For political ideology example, it had ever been happened among ASEAN member countries with the spread of communism ideology in 1960s-1990s as the impact of the Cold War led by United States with liberalism and Soviet Union with Communism. Later in the end of 20th century, ASEAN started to open themselves and considered that communism did not became the threat anymore in the region. The conlflit of political ideology was also happened in Indonesia in 1960s when unnder Soekarno's administration. $\mathrm{He}$ strongly rejected the role of allies countries such as United Kingdom and make it considered as ideology conflict between nationalism versus colonialism-imperalism took the place. Soekarno argued that the Malaysia and Singapore were supported by the United Kingdom and make those two countries become their tool to strengthen their power in the area of Southeast Asia.

This paper will focusly discussed the conflict taken place in Southern Thailand. In beginning of 2019, Al Jazeera reported the assault happened in Wat Rattananupab Temple in Su Ngai Padi district of Narathiwat province.(Quinley, 2019) The assault resulted the killing of two monks and two others that wounded. Responding to the attack, the Thailand authorities suggested all monks in southern province to stay inside the temples. The Prime Minister of Thailand, General Prayuth Chan-o-cha also condemned that assault and instructed their officials to inverstigate the party that played behind this case. Previously, there was also attack in Thailand's deep south as it was 
happened earlier when two different attack happened on the same day. Those attacks targeted a school and a hospital which then resulted a 12 -yearold student and a soldier at the school wounded. The attacks also happened with a car bomb located in Thepa district, Songkhla province that wounded a police medic.

From this assault, the party that claimed as the suspected was the separatist and fundamentalist group in Southern Province especially the Barisan Revolusi Nasional (BRN). As hundres of violence assault happened previously, it made the assault are not unusual to be happened in Thailand's deep south. According to Zach Abuza, a professor at National War College in Washington DC who also expert on the conflict, he argued that the assault was happened as the consequence of Barisan Revolusi Nasional's frustation towards the Thailand's government because the government had rejected to make compromises with them. In 2013, when the government elected democratically, it seemed to move to better step like the concession of general amnesties and languange reforms for the Muslim-Melayu in Southern Province which claimed represented by Barisan Revolusi Nasional.

Towards this Deep South Conflict, the negotiation process has been taking that will be helped by
Malaysian government as the facilitator between the Thailand government and the Separatist Groups. The first negotiations was held first since 2013 between Thailand government under the leadership of Yingluck Shinawatra and the Barisan Revolusi Nasional (BRN). Then, the negotiations were continued to be facilitated by Zamzamin Hashim under the government of Prime Minister Najib Razak at that time between the Thai junta and Mara Patani (Majlis Syura Patani) which became an unmbrella body representing separatist groups in Southern Thailand.(Mustafa, Yusa, \& Ahmad, 2018).

Recently, The Prime Minister of Malaysia, Tun Mahathir Mohammad, has apointed an Ex-Malaysian police chief, Abdul Rahim Noor to be the facilitator aiming to end the conflict in Southern Thailand. Within his trackrecords, Rahim was remembered as the negotiator in the conflict of former Communist Party of Malaya with the Malaysian government until both parties had signed a peace deal in 1989. (Mustafa, Yusa, \& Ahmad, 2018).

As the facilitator to the conflicting issue, the negotiations will be held if there has been a request from one side between the conflicting parties. If there still no any inquiry from one side, the facilitator will be 
silent and will wait if there is any development to the issue. In February 2019, the head of dialogue, Shukri Hari, said that their decision to suspend the talks will be last until the result of Thailand's general election held in March 2019. During the series of negotiation process, Abdul Rahim Noor arranged the introductory meeting for both parties on 3th February, 2019 in Kuala Lumpur. To this introductory meeting, there was disappointment from Mara Patani side with the information that the Head of the Thailand peace dialogue, Gen Udomchai, would not attend the meeting.('The Star Online, 2019) Gen Udomchai commented that he had no appointment to meet the mara Patani delegation in Kuala Lumpur. Even, he had sent Maj Gen Kriangkrai Srirak, the committee secretary, to be present in the informal meeting with Mara Patani delegation. (Nanuam, 2019) Coming from this, Mara Patani urged the Thailand government to replace Gen Udomchai so from both side can find solution in resolving the longrunning that happened in Southern Thailand.

There might be some factors causing the rising conflict that happened in Southern Thailand. This paper will be divided into three parts. First, it will highlight the historical timeline related with the existence of Southern Province in Thailand. The second part will describe the theoritical framework that used in this paper: Theory of conflict and concept of conflict resolution. The last part, it will explain the factors that caused the conflict rise and the negotiation process that might be taken.

\section{THEORITICAL FRAMEWORK OF CONFLICT RESOLUTION}

According to Oliver Ramsbotham et al, Conflict is defined as "universal feature of human society. It takes its orginis in economic differentiation, social change, cultural information, psycological development and political organization - all of which are inherently conflictual - and becomes overt through the formation of conflict parties, which come to have or are perceived to have incompatible goals.

Furthermore, about the conflict, Johan Galtung argued that conflict can be depicted through the ABC Triangle with (A) Attitude, (B) Behaviour and (C) Contradiction. Attitude includes assumption, cognition and emotion. It also includes the perception between one party to another parties, in positive or negative perception. With the perception, in conflict, each party has their own label towards other parties. The attitude is usually influenced by the fear, dissapointment and hate. 
Then, behaviour includes the body language that shows the willingness of reconciliation or hostility with the sign of threats, coercion and destructive attacks. The last, contradiction means the incompability of goals which felt by the conflicting parties. According to Galtung, conflict can be considered as the dynamic process which the structure, behaviour and attitude are changing constantly and influencing each other. The attitudes can influence behaviours and contradictions, also the behaviours and contradictions can influence the attitudes. In order to resolve the conflict, it has to include the decreasing of conflicting behaviour, the changing of attitude and transformating relations or the conflicting and different interests regarding to the interconnectedness from those three aspects of conflicts so the resolving conflict effort can reach the sustainable solution (Hindiarto, 2015).

Another definition of conflict is coming from Bernard Mayer. He viewed the conflict as a belief or understanding that the needs, interests, wants or values of one party are not incompatible with someone's else. $\mathrm{He}$ also viewed the conflict involves an emotional reaction to a situation or interaction that shows a disagreement of some kind. Regarding the source of conflict, he classified into five sources: First, the imperfection communication. He argued that there will be hard for individuals to communicate regarding the complex matters. Second, the emotion. It can contribute to the strength and courage that allow people participating in the conflict. Meanwhile, the emotion also can contribute to prevent, moderate or control the conflict. It becomes important on how people express exact and right emotional response during the conflict. Third, the value. It is the beliefs own by the society and make people will define themselves with their core beliefs. The people will defend their value if it is under attack. During the conflict, the conflicting parties can find the memeting point on how they will share their values to support the collaborative effort. Fourth, the source is structure. It might include resources, decisionmaking procedures, time constraint, physical settings and communicaton procedures. Beside that, the structure also relate with the proximity of the conflicting parties, access to information, distribution of resources, organizational structure, legal parameters and political pressure. Fifth, the source of conflict might come from the history. It will tell about the actors of conflict, systems, issues and it will provide the information for the development of conflict. The history will affect the previous sources: communication style, emotional 
reaction, values and also the structure that people have (Anam, 2012).

Furthermore, according to Johan Galtung through his Conflict Resolution theory, there are three stages in resolving the conflicts: peacekeeping, peacemaking and peacebuilding. Peacekeeping can be defined as the process to stop or reduce the violence through the military intervention with their role as a neutral peacekeeper. In this process, the situation is depicted with the external actors (it might be third party) who do intervention to the conflict in order to reduce the tension between the conflicting parties. Peacemaking can be depicted as the process involving negotiation, arbitration, mediation with the leaders or the elites in order to reconcile the political attitued and startegies of conflicting parties. Within this process, negotiation can be taken but it might probablydifficult to achieve regarding the differences of opinion between the conflicting parties but negotiations can provide alternative possibilities. Another matter that can be done within this process is mediation. It becomes another option to reach the solution by involving the third parties to be the mediators. Peacebuilding can be defined as the process to implement the change, social, political and economic reconstruction in order to create sustainable peace. With the process, it might turn the negative peace (the absence of violence) becomes the positive peace, the situation when people feel the existence of economic welfare, effective political representation and social justice. The process of peacebuilding can be done through creating peace structure and institutions according to cooperation, justice and equality. So, the process might address the cause of conflict and prevent the conflictn parties to commit the violence (Fitri, 2019).

\section{ANALYSIS \\ History of Southern Province Thailand}

In the past, the three southern border provinces of Thailand (Pattani Province, Yala Province and Narathiwat Province) that have Muslim as the majority in the region were called as the Pattani Kingdom or "Negeri Pattani". The Pattani Kingdom was believed founded between the middle of 14th and 15th Centuries. Before that, the Islamization process taken in the southern province of Thailand people was intensively happened between the 12th to 15th Centuries. Later then, Islamization process that spreaded by Syekh Said, who coming from Kampong Pasai, brought the Pattani Kingdom became The Sultanate of 
Pattani. With the existence of the Sultanate of Pattani, it marked the area of Pattani became the center of political power, center of trade and also the place where the religion and intellectual were spreaded. With those three elements, it made the Sultanate of Pattani become one of the cosmopolitan area (Helmiati, 2011).

In 1906, according to the signing of the Anglo-Siamese Treaty, the treaty between England and Siam, the Sultane of Pattani turned becoming a number of Malay provinces under the control of Siam, so it was no longer become the Malay Kingdom. Under the treaty, it was agreed that Pattani, Narathiwat, Songkhla, Satun and Yala where located at northern Melayu the Provinces of Thailand while Kedah, Kelantan, Perlis and Trengganu were agreed included as the part of Malaysia. (Helmiati, 2011) After the unification of those five region, the clash of culture between Malay-Muslim and Thai-Buddhis was happened.

In 1939, along the Rattanakosin era (the last era of Siam), Thailand Prime Minister, Luang Phibun Songkram, changed the name of Siam into Thailand that called as today. Under the administration of Luang Phibun Songkram, he attempted to prohibit the use of Malay language, Malay dressed and Friday Praying towards the Malay people because it was contradictory with the
Constitution of Thailand. Those were opposed by the Muslim people and religion leader as they were protecting thier culture.

In April 1947, Haji Sulong bin Abdul Kadir, one of the charismatic religious leader, urged the reestablishment of an autonomous region for the Muslim in southern border province under seven point of demands: First, the one who had to govern four provinces including Pattani, Yala, Narathiwat, Satun and some part of Songkhla (Thaepha, Ja'na', Sabayoi and Nathawi district) must be the local and native person coming from the four province and elected by the people of the four provinces so they would replace all local civil servants who mostly ThaiBuddhis. Second, the percentage of all civil servants in the four provinces must be $80 \%$ Muslim. Third, the urge of Malay as the official language beside the Thai languange. Forth, Malay language must be taught in the primary schools. Fifth, regarding the implementation of law, Muslim Laws must be implemented under the Islamic court with the Muslim judge (qadhi) sat as an assistant so the court would be seperated by the civil court. Sixth, all taxes and incomes that coming from the four provinces must be used in the local of those areas. Seventh, the urge of establishment of Muslim affairs bureau, under the 
authority of the governor who mentioned in the first point, which aiming to manage Muslim affairs with fully power.This petition was rejected by the government of Thailand and Haji Sulong was arrested in 1948 and imprisoned in 1949 but then he was released in 1952.

Responding to the rule of Thailand government, some separatist groups were establsihed such as Barisan Nasional Pembebasan Patani (BNPP, 1959), Barisan Revolusi Nasional (BRN, 1963) and Pattani United Liberation Organization (PULO, 1968). Those separatist groups aimed to have full autonomy and based their view of unwillingness from the government to give the freedom in practicing their religion and delivering their aspiration. This unwillingness meaned the attempt to have a gap with thier religion and disabling the culture of Islam.

In 1981, to provide better communcation between the central government and the people in southern region, it was established Southern Border Provinces Administrative Center (SBPAC) under the administration of Prem Tinsulanonda. It was also aimed to improve the coordination among security agencies. Consequently, there were three special security laws issued by Thailand government: the Martial Law Act 1914, the Executive Decree on Government Administration in States of Emergency 2005 and Internal Security Act (ISA) 2008. Those law were enforced in the conflict zone of southern border province in Thailand.

Thereafter, the conflict was being escalated in 2004. In April 2004, there were 30 Muslim youth shot by the military in Krue Se Mosque. This mosque was monumental as it was one of the oldest mosque in Thailand that established in 15th Centuries. In October 2004, around 175 Takbai Muslim passed away in the trip after demonstrating to the government and being put in the truck with their hands were tied. After those incident happened in 2004, almost every month there would be the victim either from the military or the Buddhists.

In 2012, under the Ministry of Justice, the Thai government issued some particular policies to resolve the conflict in southern border province of Thailand. First, giving remedial to the victim of the violence and clash between Thai military and separatist group that happened before such as the clash in Krue Se Mosque. Second, resolving the violence situation in southern border province by supporting in peaceful way. Third, supporting and developing the education system and improving the infrasturcture in southern border provinces. 
In resolving the conflict, the reconciliation process has been taking from the central government of Thailand. Some efforts had been undertaken such as the establishment of National Reconciliation Committee in mediating the conflicting parties in southern border province of Thailand and through the 2013 Kuala Lumpur Dialogue Process that was publicly endorsed by the Prime Minister of Thailand, Yingluck Shinawatra, and Prime Minister of Malaysia, Najib Razak. Those two leaders were took part in a public signing ceremony for General Consensus on Peace Dialogue Process on 28th February 2013 (McCargo, 2014). Following the dialogue, the Thailand government establsihed a large negotiation team, representing by Lt. Gen. Paradorn Pattanatabut. From the separatist group who claim to be from BRN, they were represented by Ustas Hassan Taib. There would be brought to the table with Malaysia as the facilitator represented by Datuk Mohamed Thajudeen bin Abdul Wahab, Secretary of the National Security Council of Malaysia (Bangkok Post, 2013).

\section{Resolving Conflict in Southern Province Thailand}

In discussing the conflict that happened in Souther Province Thailand, it can be analysed with the
ABC Triangle from Johan Galtung. The attitude that came from this conflict is the assumption and also emotion involved because of two groups originally coming from different race. It continued by the negative perception with own label from one to the another. Most of the people in Souther Province Thailand who majority is Moslems and coming from Melayu viewed that the government did not protect and provide freedom when they are practicing their religion and delivering their aspiration. On the other side, the government of Thailand viewed that because of the Southern Province Thailand had become the area of government's sovereignty so it is a must from the government to manage the people under the authority of the government. Then, behaviour from each party also influence the dynamics of this conflict. It can be seen from what happened there in 2004 when there were 30 Muslim youth shot by the military in Krue Se Mosque. After those incident, it was reported for there also some demostrating to the government regarding the policy issued by the government. The government also continues to respond with their policy or even involved in the reconciliation process through the establishment of National Reconciliation Committee. The contradiction coming from the 
incompability of goals from both of conflicting parties regarding the position and relations of Southern Province's people with the government of Thailand. With the perspective of Bernard Mayer related with the source of conflict, it can be considered the major source is coming from the history of the Southern Province Thailand. Then, it affect the other sources regarding the communication exist between the government of Thailand and people of Southern Province Thailand, the emotional reaction coming from both parties, values that hold by each parties and also the structure exist between those two conflicting parties.

Regarding the stage of resolving conflict according to Johan Galtung, this existing conflict has reached the stage of peacemaking. It is depicted as the process involving negotiation, arbitration, mediation with the leaders or the elites in order to reconcile the political attitude and strategies of conflicting parties. Through this stage, the conflict is ongoing with the mediation. The effort can be seen by the establishment of National Reconciliation Committe through the 2013 Kuala Lumpur Dialogue Process. It begun with the introductory meeting arrenged by the Malaysia as the mediator which represented by Abdul Rahim Noor. The introductory meeting was held on 3th February,
2019 in Kuala Lumpur. Recently, there has been first meeting between the Muslim south group and the officials from the new government of Thailand. Officials of the Barisan Revolusi Nasional (BRN) demanded the government to release all people who had been suspected to have links to the armed rebellion. They also demanded to government in holding transparent investigation by security forces. The Muslim south group set out demands before step towards formal talks. Then, it is commended that the talks was very early in the process to achieve the meeting points from each parties (Aljazeera, 2019).

\section{CONCLUSION}

To summarize, the conflict taking place in Southern Province Thailand had been happening since a long time ago with it's history regarding to the ethnics existing in the Southern Province Thailand and how their relations with the government of Thailand. The dynamics of occuring conflict has been depicted on how each parties response each others. The victims is continuously reported from each parties as the impact of this happening conflict.

The conflict of Southern Province Thailand has reached the stage of peacemaking where both parties agreed to be involved in the 
mediation process with Malaysia as the mediators. Some talks and meeting has been undertaken in discussing the resolution of this conflict. Therefore, to continue the peacemaking process or mediation process, each parties has to decrease their behaviour to prevent the later conflict, changing their attitude and transforming the relations with their different interests.

\section{REFERENCES}

Aljazeera. (2019) Southern rebel group says it met Thai government (Online). Available at: https://www.aljazeera.com/news/2019 /08/muslim-armed-group-met-thaigovernment-190817060220489.html (Accessed: 17 August 2019).

Anam, M. Z. (2012) "Islamic Civl Society and Conflict Resolution

Muhammadiyah's Challenges Towards The Dynamics of Malaysia-Indonesia Relationship", Jurnal Hubungan Internasional, Vol. No. 2, pp. 164-165.

Badan Pusat Statistik (2015) Mengulik Data Suku di Indonesia (Online). Available at: https://www.bps.go.id/news/2015/11 /18/127/mengulik-data-suku-diindonesia.html (Accessed: 18 November 2019).

Bangkok Post. (2013) Text of the agreement between Thailand and the BRN (Online). Available at: https://www.bangkokpost.com/thailan $\mathrm{d} /$ general/338175/general-consensuson-peace-dialogue-process (Accessed: 28 February 2019).

Fitri, R. (2019) Women's Role Towards Conflict Resolution in Liberia. Bantul: Universitas Muhammadiyah Yogyakarta.

Helmiati. (2011) Sejarah Islam Asia Tenggara. Pekanbaru: Zanafa Publishing.
Hindiarto, D. A. (2015) Upaya Pemerintah Filipina pada Masa Rodrigue Duterte dalam Menangani Konflik Minoritas Bangsamoro Tabun 2016-2018. Bantul: Universitas Muhammadiyah Yogyakarta.

McCargo, D. (2014) Sothern Thailand: From conflict to negotiations? Sydney: Lowy Institute for International Policy.

Mustafa, M., Yusa, Z., \& Ahmad, M. (2018) Malaysia Appoints New Facilitator for Southern Thai Peace Talks (Online). Available at: https://www.benarnews.org/english/n ews/malaysian/peace-facilitator08242018162911.html (Accessed: 24 August 2018).

Nanuam, W. (2019) Peace talks chief counters southern rebels' condemnation (Online). Available at: https://www.bangkokpost.com/thailan d/general/1623342/peace-talks-chiefcounters-southern-rebelscondemnation (Accessed: 4 February 2019).

Quinley, C. (2019, January 21) Attacks in Thailand's deep south: Who, why and what's next? (Online). Available at: https://www.aljazeera.com/news/2019 /01/attacks-thailand-deep-south190120233033431.html (Accessed: 24 January 2019).

Surwandono, \& Ahmadi, S. (2011) Resolusi Konflik di Dunia Islam. Yogyakarta: Graha Ilmu.

The Star Online. (2019) Malaysia ready to facilitate Southern Thailand peace dialogue upon request, says Rabim Noor (Online). Available at: https://www.thestar.com.my/news/nat ion/2019/02/04/malaysia-ready-tofacilitate-southern-thailand-peacedialogue-upon-request-says-rahimnoor/ (Accessed: 4 February 2019). 